\title{
The Value of Siri'na Pacce as an Alternative to Settle Persecution
}

\author{
Hijriani, ${ }^{*}$ Herman ${ }^{* *}$ \\ DOI: https://doi.org/10.22304/pjih.v5n3.a9
}

Submitted: August 2, 2018 | Accepted: January 10, 2018

\begin{abstract}
The increasing cases of persecution have led to the building of negative image and public distrust of the state and the law enforcement process. Persecution, as an act that is harmful, troubles, and oppresses others, is included as a criminal offense. The Makassarese recognizes shame culture as a part of the siri cultural system. It is completed by empathy in the concept of pace. Both are referred by the term siri' na pacce. This value can be implemented and developed to be an alternative to settle the cases of persecution. It is in line with the concept of legal objectives as a philosophy in all aspects of life and obedience to society because it is more entrenched and considered sacred. This study used qualitative research and normative juridical methods. This study aims to find weaknesses and strengths of the value of siri'na pacce as a new alternative to settle persecution in realizing justice and building social harmonization within society. The results reveal that re-instilling the siri culture can be a valuable effort to restraint someone from performing an act of persecution. People can be prevented and prohibited to do such act by adhering to customary rules. It is expected that upholding the siri'na pace value can strengthen the motivation of social solidarity. Therefore, the cultural value is expected to be maintained and becomes an alternative to settle persecution cases, considering that it is more effective and efficient because the community can accept it easily.
\end{abstract}

Keywords: alternative solutions, persecution, siri'na pacce value.

\section{Nilai Siri' Na Pacce sebagai Alternatif Penyelesaian Tindakan Persekusi}

\begin{abstract}
Abstrak
Meningkatnya kasus persekusi menyebabkan terbangun stigma negatif dan ketidakpercayaan publik terhadap negara dan proses penegakan hukum. Persekusi sebagai tindakan kejahatan menyakiti, untuk mempersusah dan menumpas orang lain termasuk sebagai tindak pidana. Nilai malu sebagai bagian dari sistem nilai budaya Siri' dan nilai pedih karena melihat penderitaan orang lain, menjadikan konsep Pacce tampil berpadanan menjadi siri' na Pacce. Nilai tersebutdapat diimplementasikan dan dikembangkan menjadi alternatif penyelesaian persekusi karena sesuai dengan konsep tujuan hukum sebagai falsafah dalam segala aspek kehidupan dan ketaatan masyarakat karena lebih mengakar dan dianggap sakral. Artikel ini menggunakan penelitian kualitatif dan metode yuridis normatif. Adapun tujuan penelitian ini untuk menemukan kelemahan dan kelebihan nilai Siri' Na Pacce sebagai alternatif baru penyelesaian persekusi dalam mewujudkan keadilan dan membangun harmonisasi sosial dalam masyarakat. Hasil penelitian menunjukkan bahwa dengan menanamkan kembali nilai malu
\end{abstract}

PADJADJARAN Journal of Law Volume 5 Number 3 Year 2018 [ISSN 2460-1543] [e-ISSN 2442-9325]

* Lecturer of the Faculty of Law, Universitas Halu Oleo, Jl. H.E.A. Mokodompit Kendari Sulawesi Tenggara, hijriani@uho.ac.id, S.H. (Universitas Hasanuddin), M.H. (Universitas Muslim Indonesia).

** Lecturer of the Faculty of Law, Universitas Halu Oleo, J. H.E.A. Mokodompit Kendari Sulawesi Tenggara, man.herman76@yahoo.com, S.H. (Universitas Muslim Indonesia), M.H. (Universitas Gadjah Mada), Dr. (Universitas Airlangga). 
dalam budaya siri' terutama berfungsi sebagai upaya pengekangan bagi seseorang untuk melakukan tindakan persekusi dapat dicegah serta dilarang oleh kaidah adat dapat menguatkan motivasi solidaritas sosial dalam penegakan harkat Siri' $\mathrm{Na}$ Pacce orang lain sehingga diharapkan nilai budaya ini dapat dipertahankan dan menjadi alternatif penyelesaian tindakan persekusi yang pelaksanaannya lebih efektif dan efisien karena mudah diterima masyarakat.

Kata kunci: alternatif penyelesaian, nilai siri'na pacce, persekusi.

\section{A. Introduction}

Various conflicts, either horizontal or vertical conflicts, in Indonesia have various characteristics. Horizontal conflict refers to conflict that grows among members of community, for example conflicts that have nuances of ethnicity, religion, race, and intergroup. On the other hand, vertical conflict is a conflict that involves community and state. In general, this conflict occurs because of dissatisfaction on the way the government works, for example conflicts of workers or regional conflicts with the emergence of separatist movements.

The growing number of crimes indirectly raises a presumption from the public that law enforcement officers fail to overcome problems and are considered slow in carrying out their duties. This is due to the lengthy process of the judicial system that is less-educated, long, and complicated processes. For instance, law enforcers often release suspects because there is a lack of evidence. The fact of course is not in accordance with people's expectations. Therefore, some people feel disturbed and insecure. They no longer trust law enforcement officers, so they take vigilante actions against crime perpetrators without following the applicable legal process. This can be seen lately a lot of news of persecution in Indonesia.

The increase of horizontal conflict, especially persecution cases, which are widely reported in the mass media raises questions regarding the term "persecution". For instance, people keep questioning the extent to which the definition of persecution and whether the use of the term is appropriate. This needs to be a specific consideration, especially in the law enforcement. Persecution to the crime perpetrators is considered to have harassed and ignored law enforcement of the state. Many persecution cases are also found on social media but not everyone knows or understands the true meaning of the term. Cases of persecution have recently raised concerns among the people. The actions seem to be an increasing trend in terms of quantity.

Persecution covers an attempt to intimidate and to perform acts of violence with the purpose that the victims of persecution follow the wishes of the perpetrators. The most worrying of some cases of persecution is that the law enforcement is processed based on mass pressure. Therefore, people increasingly question the consistency and independence of law enforcement.

Local wisdom that is rooted and reflected through attitudes, morals, and deeds is considered a guide for the people to resolve conflicts. Wisdom is formed from the introduction, understanding, experience, and practice of religious and cultural values in 
the form of living ethics. Local rules based on socio-cultural conditions illustrate the harmony of ways of thinking and living.

Indonesia is a state with a strong culture. Therefore, it should be able to prevent acts of persecution, since culture is actually a moral foundation that teaches goodness. From the aspect of ontology, siri'na pacce culture has a very strong relationship with the view of Islam in the framework of spirituality, where the power of the soul can be actualized through the conquest of the soul over the body. The core of the siri'na pacce culture covers all aspects of the life of the Bugis-Makassarese people because siri' na pacce is the identity of the Bugis-Makassarese people. The existence of the siri'na pace, as a philosophy and ideology enable the bond between each other. The solidarity can become stronger, both with fellow tribes and with other tribes. The concept of siri'na pacce is not only shared by two tribes (Bugis and Makassar). Other tribes who inhabit the land of Sulawesi such as the Mandar and Tator people also adopt it. The different is only on vocabulary and accent to mention it. Basically, the ideological philosophy has similarities.

In the culture of the people of Bugis and Makassar, a philosophy of life, moral ethics, and a principle originates from the teachings of previous ancestors. The culture of Bugis-Makassar is a culture practiced by the largest part of the southern coast of Sulawesi. The value of Siri'na pacce among the Bugis-Makassarese almost equals to the Bushido spirit of the Japanese Samurai that emphasizes the value of loyalty, justice, shame, manners, responsibility, and honor. One of the 'Siri' values is shame. It means that the Bugis-Makassarese must maintain their dignity and respect. Pacce means sympathy. The Bugis-Makassarese people have a spirit of solidarity and a high sense of empathy towards others. The concept of Siri covers internal scale, while pacce covers internal and external. These two values can be used as a basis for framing persecution as a shameful act, undermining human dignity, and not in accordance with the philosophy that upholds sympathy, empathy, and solidarity.

A. Moein MG $^{1}$ assumes that Siri' is the philosophy, or the view, of life of Indonesian people containing ethics of morality in the form of recommendations, prohibitions, rights and obligations. It becomes a way of life to maintain, or to increase, human dignity, group honor, and uphold the dignity of God. Siri' is also a motivation to change, to improve, and to develop the fate of individuals and groups (Budidarmo, 1997: 16-17). It contains knighthood, honesty, obedience to parents, teachers, and leaders, humanity, a sense of love, a spirit of shared fortune, determination to defend the truth and eradicate crime, obedience to applicable laws, willingness to sacrifice to defend humanity and justice, and devotion to The One Almighty God.

It can be said that the siri' values give great impacts on the attitude of the BugisMakassarese and, in general, all people of South Sulawesi. Nevertheless, the siri' value for the Bugis-Makassarese, as described above, is a part of the philosophy of life. Based on the above analysis, the real role of siri' is the subconscious of the BugisMakassarese is a philosophy and attitude that embodies the Bugis-Makassarese community.

${ }^{1}$ A. Moein MG, Sirik Na Pacce, Kualleangnga Tallanga Na Toalia, Ujung Pandang: Yayasan Makassar Press, 1994, p. 22. 
Based on the philosophical values, the siri'na pacce culture can be divided into the following.

\section{Philosophical Value}

The philosophical value of siri'na pacce is the views of the Bugis and Makassar people about various life issues, which include the character of the BugisMakassarese who are reactive, militant, optimistic, consistent, loyal, courageous, and constructive.

\section{Ethical Value}

In the siri'na pace, ethical values there are values that include firm stance, faithful, self-aware, honest, wise, humble, polite, love, and empathy.

\section{Aesthetic Value}

The aesthetic value of siri'na pacce includes lifeless natural objects, plant-based natural objects, and animal-based natural objects. Then, one thing that needs to be considered here is when the pride of a Bugis-Makassarese is tarnished, which hence giving birth to aspects of siri', then it should be for those affected by siri' to make efforts to eliminate the stain (siri'). This can be in the form of deliberation or discussing the issue or if it has crossed humanitarian boundaries and existing provisions, then the efforts can be in the form of strength (both legally and individually), depending on the siri' value that arises from the existing problems. Those who are affected by siri' but keep silent without any effort at all will be dubbed as a person who has no shame (tau tena sirina).

Pesse' is closely related to identity. Pesse' is a binding tool for members of social group. It certainly is applied to ethnic group. Between fellow Bugis people, especially seafarers or migrants who live overseas, Pesse underlies their sense of "Bugis-identity". It becomes a "sempugi" among fellow Bugis people. Therefore, there is a saying, "lya sempugi'ku, rekkua de'na siri'na, engka messa pesse'na" (When my fellow Bugis (sempugi'ku) do not put siri' on me, at the very least, they still leaves me pesse).

The mutual feeling of Pesse among members of a group is an important unifying force. The agreement between two persons to become "fellow brothers", as well as awareness as a member of the same group, brings responsibility that should not be ignored, so as not to lose honor. The saying mentions, pauno siri', ma'palete pesse ri pa'masareng esse' (honor can cause your death and compassion can take you to the afterlife). This means that siri' and pesse' must contain a balance to neutralize each other's extremes. ${ }^{2}$

Based on the description, this study aims to provide an overview of the siri'na pacce culture transform good people who respect fellow human beings, teach to be empathy, and help other people. In other words, the internalization of sirina pacce values in certain societies has an important role to shape human character and personality as individuals and societies, even though the modernity has alienated local wisdom. Maintaining cultural value means filtering the hegemony of globalization so that it can prevent problems, especially to minimize the occurrence of persecution. The

Nurdin Yatim, Sub Sistem Honorifik Bahasa Makassar Sebuah Analisis Sosiolinguistik, Jakarta: Direktorat Pembinaan Penelitian dan Pengabdian pada Masyarakat (Dirjen Dikti), 1983, p. 33. 
cultural value of siri'na pacce is also a tool to control attitudes and behavior of each individual and to form a moral and ethical society. Thus, it is expected that the siri'na pacce culture can be maintained and preserved to minimize the occurrence of conflicts, especially persecutions. Then as a preventive measure effort to resolve conflicts in Indonesia, especially persecution, people may think about returning to their own culture.

The awareness of siri' value through adat leaders to disputing parties can be an entry point to open a path to a favorable solution for the disputing parties to prevent the occurrence of other acts of persecution. This application can be a new alternative to settle persecution, mainly in realizing justice and building social harmony, within community. The benefits cover all parties associated with the efforts to make the cultural value as a settlement of persecution in the community can be responsible both in the process and in its implementation. The culture of each region is unique but values and ethics that traditionally form behaviors are guides that will complement the rules and policies and harmonize with each other. The community will be able to maintain and uphold national identity and be in harmony with the cultural values of the region by preserving the cultural values of siri'na pacce.

\section{B. The Background of Persecutions}

In general, conflicts are triggered by differences. Differences are an inseparable part of the reality of life. Potentially, differences can cause problems. Therefore, it should be well understood and managed constructively to further enrich the meaning of life. It can cause a problem when people seek the solution of difference by means of violence. Conflicts can also be positive when it can be managed wisely and intelligently so that it makes social processes dynamics and constructive for social change without violence. Then, a conflict can be a source of change. ${ }^{3}$

Soerjono Soekanto classifies the forms and types of conflicts as follows:

1. Personal conflict of a person against another person.

2. Racial conflict.

3. Inter-social class conflict.

4. Inter-political group conflict in a community or between sovereign states.

5. International conflict.

Persecution itself can be classified into a part of conflict because either the perpetrator or the victim may not be limited to one person but it can also be a group of people, communities, and even state.

Persecution may also be a form of indirect criticism of the law enforcement system in Indonesia. Persecution can occur due to two factors. First, the law awareness and understanding of a community is low. Second, there is a distrust of law enforcement officials. There are various negative perceptions that develop among people, where members of communities are in mutual suspicion. If it continues to develop, it will lead to disharmony and a social crisis. Social crisis may easily trigger various conflicts,

Abdul Jamil Wahab, Manajemen Konflik Keagamaan Analisisi Latar Belakang Konflik Keagamaan Aktual, Jakarta: Elex Media Komputindo Kompas-Gramedia, 2014, p. 6. 
especially when there is a momentum. The conflict can be in the form of looting, destruction, arson, persecution, and even murder.

Principally, three aspects lead to persecution ${ }^{4}$ as follows.

1. The existence of personal interests of people who receive or read messages from other people outside their groups.

2. The determination to show existence to and to punish anyone, who acts and is considered "wrong". In short, it is reply message to not recklessly send any messages because the people in the community will monitor and act. For example, the burning of robbers' motorbikes is included in this category.

3. The decreasing public confidence in the law. Law enforcement by law officials is seen as no longer able to realize justice for the people who have the equal rights and obligations before the law. The community hopes that all processes will run quickly and in accordance with their expectations so that the law enforcement process must be carried out quickly and instantly. This means that once there is a mistake, action should be taken immediately; the perpetrator should be punished instantly.

Based on the communication perspective, persecution is present because of various communications that are hampered or blocked. Communication barriers occur because of several things as follows. ${ }^{5}$

1. Mechanical disorder is the occurrence of a disturbance in communication channel or noise that is physical and more directed to the medium used in communication, such as multiple sounds on the radio because of waves that coincide, or the noise of the audiences when people make speeches.

2. Semantic disorder is concerned with understanding actual words or changing understanding of words. The symbol of the same words has different meanings for different people. This is due to two types of understanding of words that have a denotative meaning or in accordance with the dictionary and connotative, namely the understanding that depends on the emotional and background of a person.

3. Interest factor will also hinder effective communication because people will be more selective in receiving and responding to messages. People will be more responsive to the messages that are in accordance with their needs. In the midst of high information and endless debates due to various issues that spread among the citizens, the interest factor makes clash. Hate speech never stop because artificial loyalty that goes hand in hand with viral messages. Many people are connected each other and create their own groups and communities. Social media is the most powerful medium for the formation of this loyal community.

4. Motivation factor affects the level of concern, attention, and stimulation of message. The more appropriate a message is with one's motivation, the higher level of intensity and the higher attention appears. If we relate to the context of persecution, motivation of perpetrators and victims who sometimes also commit verbal violence on social media is actually born because their motivation is no

\footnotetext{
Mustafa, "Persekusi dalam Perspektif Komunikasi”, https://uin-suska.ac.id/2017/07/11/persekusi-dalam-perspektifkomunikasi/, accessed on July 2018.

5 Onong Uchjana Effendy, IImu, Teori dan Filsafat Komunikasi, Bandung: Citra Aditya Bakti, 2003, p. 47.
} 
longer upholding the truth. This non-uniform motivation causes communication between the two parties to be no longer rational. It is not in accordance with the logic of sound thinking because it is based on negative sentiments towards the parties who argue.

5. Prejudice is a serious obstacle to the communication process, suspicion on message makes communication ineffective. Prejudice makes someone drawing conclusions based on emotion and being subjective leading to irrationality. Because of this trait, a perspective that forms boundaries of communication and relationships among the people may arise.

Persecution nowadays enters the digital domain. Upload of images, videos, sentences that are spread in social media pages, so the disgrace of persecution victims becomes a viral spectacle and is consumed by every social media user. The victims of persecution also face intimidation in such a way. They are even hunted and targeted by a group of people. This is clearly a violation of privacy and a form of vigilante against other people without legal process.

\section{Definition of Persecution}

Persecution is a noun, derived from a verb 'to persecute', which means arbitrary hunting of a person or a number of citizens. ${ }^{6}$ The active word "to persecute" means to change into torture: without thinking about justice or humanity. In short, persecution is a mistreatment or systematical vigilante by individuals or groups of individuals, mainly because of ethnicity, religion, or political views. ${ }^{7}$

In Indonesian language, a vigilance action is better known as persekusi. It refers to "Arbitrary hunting of someone or a number of residents who are then hurt, troubled, or oppressed". In English, persecution means "hostility and ill-treatment, especially because of race or political or religious beliefs".

\section{Persecution in the National Legal Framework}

Based on Article 1, paragraph (3), of the 1945 Constitution of the Republic of Indonesia: "Indonesia is a legal state". Grammatically, there is a consequence of a legal state, namely that all forms of decisions, actions of state equipment, all attitudes, behavior and actions must have a legal basis or legitimacy. However, the reality of criminal law among the people of Indonesia is not as easy as the theory. Many complex problems, including criminal acts, occur, along with the development of society towards the modern era.

The growing number of crimes indirectly raises a presumption from the public that law enforcement officers fail to overcome problems and are considered slow in carrying out their duties. This is due to the lengthy process of the judicial system that is less-educated, long, and complicated processes. For instance, law enforcers often release suspects because there is a lack of evidence. The fact of course is not in accordance with people's expectations. Therefore, some people feel disturbed and

\footnotetext{
Kementerian Pendidikan dan Kebudayaan RI, "Kamus Besar Bahasa Indonesia", https://kbbi.kemdikbud.go.id/persekusi, accessed on July 252018.

7 Ibid.
} 
insecure. They no longer trust law enforcement officers, so they take vigilante actions against crime perpetrators without following the applicable legal process. This can be seen lately a lot of news of persecution in Indonesia.

The state should not tolerate any act of persecution. If every act of persecution is allowed, there will be a negative stigma and public distrust of the state and law enforcement. There can be a presumption that a problem can be solved arbitrarily by ignoring the rules and laws in effect. Victims may feel insecure to live in their environment even in their own state and the law can be considered weak and helpless before a mob of citizens who act arbitrarily.

Many persecutions happen because of anger. Vigilante acts in Indonesia are generally known by the communities. It is the actions of a group of people, in which they catch and torture a criminal suspect. In some cases, victims of persecution were "stripped naked", lost their jobs, and were bullied. These can be classified vandalism since their actions cannot be justified legally. Up to this point, one may ask about supervision and responsibility of the state to protect the rights and the privacy of its citizens. Indonesia is a legal state that theoretically guarantees security, public order, and provides protection to every citizen. The consistency of law enforcement must be practiced and proven through the application of material law and formal law.

The principle of the rule of law is to protect human interests against dangers that threaten and regulates relations among human beings. The rule of law functions to protect human interests, both individual and groups. Therefore, people who have legal interests must live it out, obey, carry out, and enforced it. Mertokusumo says that human awareness is basically a human need for the protection of interests, namely a law that is obeyed and carried out and enforced so that their interests and interests of others are protected from threats around them. 8

In law, persecution is known as vigilante. Basically, it is an action to carry out rights according to one's own will without the consent of other interested parties. It is the implementation of sanctions by individuals. ${ }^{9}$ Persecution within the Indonesian legal framework is regulated in the Law Number 26 of 2000 on Human Rights Courts. The law adopts genocide and crimes against humanity as forms of human rights violations. Persecution is regulated in Article 9 (h). Thus, persecution can be processed based on the Law. 10

Persecution or vigilante action is not regulated clearly and explicitly in the Criminal Code or other laws. However, the consequences of persecution can be included in several types of crimes, such as unpleasant actions, threatening, harassment, and abduction. Explicitly, they are explained in Book II (Indonesian Criminal Code). This action is contrary to the principle of presumption of innocence, so that victims of

\footnotetext{
Sudikno Mertokusumo, Teori Hukum, Yogjakarta: Cahaya Atma, 2012, p. 17.

Agen Sindikat, "Kamus Hukum Terlengkap - 11.000 istilah bahasa Inggris \& Belanda", https://www.academia.edu/16083005/Kamus Hukum Terlengkap - 11.000 istilah bahasa Inggris and Belanda, accessed on July 2018.

10 Yayasan Lembaga Bantuan Hukum, "Artikel Diskusi Persekusi", http://www.ylbhi.or.id/2017/07/artikel-diskusipersekusi/, accessed on July 2018.
} 
persecution cannot be punished guilty or not before going through a judicial process and a judge's decision. ${ }^{11}$

A crime can be categorized as persecution if it fulfills six elements of crime as follows ${ }^{12}$.

First, a crime perpetrator eliminates other people's basic rights. Second, a crime perpetrator targets someone or a group of people based on different identity. Third, a crime perpetrator targets someone or a group of people based on politics, race, nationality, ethnicity, culture, religion, gender, or other reasons that are universally prohibited in international law. Fourth, the act is associated with any act as stipulated in Article 7 (1) of the Rome Statute of the International Criminal Court 1998 (Rome Statute), that includes murder, extermination, slavery, deportation or forced displacement of citizens, imprisonment, or pressures of freedom by cruel physical violations, torture, abduction/enforced disappearance, crimes of apartheid, or other crimes that are the jurisdiction of the International Criminal Court (ICC). Fifth, the crime is carried out as part of a widespread and systematic attack aimed at a certain group of civilians. The sixth, the perpetrator knows that the action constitute, or intentionally become, a part of a widespread and systematic attack on certain civilian groups.

The police emphasize that the act of persecution is against the law. There are four legal processes to ensnare the perpetrators of persecution as follow.

1. A perpetrator who enters a house or an office without permission can be the subject to Article 167 (1) of the Indonesian Criminal Code facing the sentence of one-year imprisonment.

2. A perpetrator who carries out coercive action can be charged under Article 335 of the Criminal Code facing the sentence of five years imprisonment.

3. Two perpetrators who bring a victim to a place by force so that the victim cannot contact the outside world is categorized a kidnapping.

4. A perpetrator who commits maltreatment can be charged with Article 351 of the Criminal Code facing the sentence of two years in prison. If the persecution is carried out together, they can be the subject to Article 170 of the Criminal Code facing the sentence of five years prison. ${ }^{13}$

Perpetrator who carries out persecution can be the subject to several articles contained in the Criminal Code as follows. ${ }^{14}$

1. Article 368 on extortion.

11 Hijriani Hadz, "Budaya Indonesia Jaman Now", https://locita.co/esai/persekusi-budaya-indonesia, accessed on July 2018.

12 Amzulian "Kejahatan Persekusi atau Tindakan Intimidasi?", https://nasional.sindonews.com/read/1211732/18/kejahatan-persekusi-atau-tindakan-intimidasi-1496878262, accesed on July 2018.

13 Martinus Sitompul, "Empat Jeratan Hukum untuk Pelaku Persekusi", https://kumparan.com/@kumparannews/polisi-ada-empat-jeratan-hukum-untuk-pelaku-persekusi, accessed on July 2018.

14 R. Sugandhi SH, KUHP dan Penjelasannya, Surabaya: Usaha Nasional, 1980, p. 112. 
"Any person who, with integer to unlawfully benefit himself or another, by force or threat of force forces someone either to deliver a good that wholly or partially belongs to that person or to a third party or to negotiate a loan or to annul a debt, shall, being guilty of extortion, be punished by a maximum imprisonment of nine years."

2. Article 369 on threats

"Any person who, with intent to unlawfully benefit himself or another, by threat of slander, libel revelation of a secret forces someone either to deliver any property which wholly or partially belongs to that person or to a third party, or to negotiate a loan or to annul a debt, shall, being guilty of black-mail, be punished by a maximum imprisonment of four years."

3. Article 351 on Persecution.

(1) Maltreatment shall be punished with a maximum imprisonment of two years and eight months or a maximum fine of three hundred rupiahs.

(2) If the act results in a serious physical injury, the offender shall be punished with a maximum imprisonment of five years.

(3) If the fact results in death, he shall be punished by a maximum imprisonment of seven years.

(4) With maltreatment shall be identified intentional injury to the health.

(5) Attempt to this crime shall not be punished.

4. Article 170 (1) on mass beating.

"Persons who with united forces openly commit violence against persons or property, shall be punished by a maximum imprisonment of five years and six months."

5. Article 335 on physical or non-physical violence.

(1) By a maximum imprisonment of one year or a maximum fine of three hundred rupiahs shall be punished:

$1^{\text {st }}$, any person who unlawfully forces another by force, by any other battery or by an offensive treatment or by threat of force, of any other battery, or also of an offensive treatment, aimed either against the other person or against a third party, to do, to omit or to tolerate something;

$2^{\text {nd }}-l y$, any person who forces another by threat of slander or libel to do, to omit or to tolerate something.

(2) In the case described under 2nd-ly, the crime shall not be prosecuted except upon complaint by the person against whom it has been committed.

Based on some articles above, Article 351 on persecution is the most relevant. According to Sianturi ${ }^{15}$, there are six categories of persecution in the Criminal Code as follows.

1. Unpretentious/simple persecution in Article 351. This category is given to distinguish it from the persecutions, which are determined in the next articles.

2. Mild persecution in article 352 .

3. Planned unpretentious persecution plans in Article 253.

15 S.R. Sianturi, Tindak Pidana di KUHP berikut uraiannya, Jakarta: Alumni AHM-PTHM, 1983, p. 18. 
4. Severe persecution in Article 354.

5. Planned severe persecution in Article 355.

6. Persecution of special objects in Article 356.

There is also another category called intangible persecution. For instance, it may be in the form of serious restrictions on basic rights to identity/group, such as the right to worship, the right to get a job, the right to education, and other rights, which are considered basic human rights.

Indonesia also has Human Right Courts Law that adopt genocide and crimes against humanity as a form of human rights violations. Persecution can be categorized as a crime against humanity, as stipulated in Article 9 (h) as follows.

"terrorization of a particular group or association based on political views, race, nationality, ethnic origin, culture, religion, sex or any other basis, regarded universally as contravening international law"

The persecution that occurs in social media is regulated in the Law Number 19 of 2016 on the Amendments to the Law Number 11 of 2008 on Information and Technology as follows.

1. Article 27 (4): "No Person shall intentionally and unauthorizedly distribute and/or transmit and/or cause to be accessible Electronic Information and/or Electronic Records with contents of extortion and/or threats."

2. Article 28 (1): "No Person shall intentionally and unauthorizedly disseminate false and misleading information resulting in consumer loss in Electronic Transactions."

3. Article 28 (2): "No Person shall intentionally and unauthorizedly disseminate information with intent to incite hatred or dissension on individuals and/or certain groups of community on the basis of ethnic groups, religions, races, and intergroups (communal disturbances)."

4. Article 45 (1): "Any Person who satisfies the elements of Article 27 section (1), section (2), section (3), or section (4) shall be sentenced to imprisonment of at most 6 (six) years and/or a fine of at most Rp1,000,000,000 (one billion rupiah)."

5. Article 45 (2): "Any Person who satisfies the elements of Article 28 section (1) or section (2) shall be sentenced to imprisonment of at most 6 (six) years and/or a fine of at most Rp1,000,000,000 (one billion rupiah)."

\section{E. Persecution in the International Legal Framework}

In the Rome Statute, persecution is the emergence of suffering, harassment, detention, fear, and various other factors. However, only severe suffering can be classified as persecution.

In the development of international criminal law, the definition of persecution has expanded with the enactment of the Rome Statute. In Article 7 (2) (g) of the Rome Statute, persecution is also included a crime against humanity. In the Rome Statute, persecution is defined as "'persecution' means the intentional and severe deprivation of fundamental rights contrary to international law by reason of the identity of the group or collectivity".

In determining whether there is persecution or not, Cohen emphasized two levels of verification. The first is the contextual element of persecution, namely the 
knowledge of perpetrator that their action is a part of a systematic or widespread attack on the civilian population. The second is discrimination against victims, groups, or collectivities where they are part of politics (not necessarily institutionalized), race, citizenship, ethnicity, culture, religion, gender, or others that are prohibited under international law. The perpetrators of persecution can be anyone, not only government or state organs, including civilian. ${ }^{16}$

Cohen further explains that persecution is one form of action that is included in crimes against humanity since 1993 with the adoption of the Statute of the International Tribunal for Rwanda (ICTR). A year later, in the Statute of the International Tribunal for Crimes in the Former Yugoslavia (ICTY), persecution is also included as a form of crime against humanity. Both of these Statutes have similarities in defining persecution as a form of crime against humanity in the context of widespread or systematic attacks on civilians. Persecution is carried out with the intention to discriminate based on race, politics, or religion.

The word 'persecution' exists in the Rome Statute. The Statute is a product of the United Nations in the formation of the ICC. The Statute was established in Rome, 1998. Article 1 states that the establishment of the ICC is to deal with "the most serious crimes of international concern". Article 5 mentions the crimes that are included in the Court Jurisdiction is limited to the most serious crimes involving the international community as a whole. The Court has jurisdiction which is in accordance with the Statute related to: (1) crime of genocide; (2) crimes against humanity; (3) war crimes; (4) crime of aggression.

Persecution falls into the category stipulated in Article 7, paragraph 1 (h), as a crime against humanity:

(1) "For the purpose of this Statute, 'crime against humanity' means any of the following acts when committed as part of a widespread or systematic attack directed against any civilian population, with knowledge of the attack:"

(h) "Persecution against any identifiable group or collectivity on political, racial, national, ethnic, cultural, religious, gender as defined in paragraph 3 , or other grounds that are universally recognized as impermissible under international law, in connection with any act referred to in this paragraph or any crime within the jurisdiction of the Court;".

Then the definition of persecution itself is contained in Article 7, paragraph 2 (g):

"Persecution' means the intentional and severe deprivation of fundamental rights contrary to international law by reason of the identity of the group or collectivity." 17

\section{F. Siri'na pacce as an Alternative to the Settlement of Persecution}

Bagir Manan ${ }^{18}$, former Chair of the Supreme Court of the Republic of Indonesia, highlights the fact that in the settlement of persecution case is not in the framework of

16 IAIN Tulungagung, "Persekusi Menurut Hukum Pidana”, http://repo.iain-tulungagung.ac.id/8157/6/BAB\%20III.pdf, accessed on July 2018.

17 Rome Statute of the International Criminal Court 1998 (Rome Statute). 
law. He states that the settlement in our customary law is not limited to civil disputes. It is also common in criminal cases. Frequently, crime act is settled in an amicable manner. For instance, in the event of a death due to fight, amicable solution brings compensation for the victim's family. Compensation is not only material. The compensation can also be immaterial, such as customary fines, the obligation to do something to restore balance. In fact, statements of remorse and sincere apologies received by the victim's family are often the basis of important peace. Moreover, this kind of amicable effort must have a legal consequence to close case after the settlement. Therefore, the doctrine that says the nature of criminal is not erased after settlement so that the case should continue should be abolished.

The existence of law is required to respond to all problems and community interests. Law as a social engineering tool must be based on kokoro ${ }^{19}$ aspiration of people. To achieve this goal, legal certainty is needed so that the basic needs for welfare, prosperity, and justice can be fulfilled. This is done so that the law does not work in a vacuum. In line with that, Esmi Warassih Pujirahayu says that if the law does not want to be said to be lagging behind the development of its society, the law is required to respond to all ins and outs of the social life that surrounds it. Thus, the role of law becomes increasingly important in dealing with social problems. ${ }^{20}$

The existence of customary law in Indonesia with its local wisdom that had existed before the Indonesian independence is one of the specialties of law in Indonesia. Customary law in the process of settling the dispute prioritizing the win-win solution that is often preferred because it is felt capable of fulfilling the sense of justice, rather than resolving the problems through the court. Moreover, the settlement of criminal cases by using a repressive approach as implemented in the Criminal Justice System has resulted in retributive justice, which is oriented towards retaliation in the form of punishment and imprisonment. The implementation of retributive justice is deemed not to produce justice for all parties, especially victims.

Conflict resolution in certain cases should be adapted to the context and setting in which conflict occurs because in the case of a universal approach, it is actually no longer relevant to be applied in dealing with conflict issues. Usually, conflict resolution using universal theoretical approaches leads to an incomplete resolution of the conflict and finally the conflict recurs so that it does not provide positive change. Conflict resolution with local wisdom can be introduced by introducing local wisdom itself. In addition to being useful as an alternative to conflict resolution, local wisdom also maintains and adheres to national identity.

The approach of local wisdom is unique in every region. In fact, local wisdom remains rooted in a culture that local community has. Local wisdom is the most effective media to find solutions to conflict resolution. This condition is carried out by

18 Bagir Manan, “Mediasi Sebagai Alternatif Menyelesaikan Sengketa”, Varia Peradilan, No. 248, July 2006, pp. 10-11.

19 "The term kokoro means a conscience, which is a method of law in Japan, even though the nation is modern, but they still maintains the kokoro" in Satjipto Rahardjo, Mendudukan Undang-undang Dasar (Suatu Pembahasan dari Optik Ilmu Hukum), Semarang: Badan Penerbit Universitas Diponegoro, 2007, p. 15.

20 Esmi Warassih, Pranata Hukum (Sebuah Telaah Sosiologis), Semarang: Badan Penerbit Universitas Diponegoro, 2011, p. 1. 
inviting the people involved in the conflict to discuss and negotiate each other's wishes towards the other party. This will have an effect on the form of settlement that is considered possible and appropriate and can be used as an early warning system of conflict. ${ }^{21}$

By understanding the value and meaning of Siri'na pace, many positive things can be adopted as an alternative concept of solution. The value upheld human values, fair attitudes, and caring and paying attention to the interests of others.

Law enforcement in the act of persecution is basically not only as a defense of the law in mere repressive actions but it also includes preventive measures. Preventive law enforcement can be carried out with a control system, supervision, providing convenience, and reward for those who run or obey the law. Law enforcement also prevent possible violations of law or illegal acts. ${ }^{22}$ Thus, sanctions are not merely in the sense of giving suffering (body, property, life), but also including appreciation. Sanctions in this broad sense are often referred to as punishment and reward. ${ }^{23}$

Coherently, community plays a role in law enforcement. Settlement institutions outside court mediation, conciliation, or arbitration are examples of community participation in law enforcement among themselves. Likewise, social and customary sanctions can be seen as forms of law enforcement by the people. However, it should be noted that self-judgmental actions (acts of persecution) is not included law enforcement. ${ }^{24}$

The application of siri'na pacce among the Bugis-Makassarese needs to involve traditional institutions led by traditional elders which are influential in community. Preventive actions are efforts to resolve conflicts, especially in cases of persecution. The process of settling persecution actions can be performed in a close family system, listening to each other, and accepting any agreed decisions as a way out of conflicts to reach the openness of mutual forgiveness, admitting mistakes, and opening the way of peace between the disputing parties.

\section{G. Internalization of the Siri'na Pacce Value as an Effort to Reduce Persecution}

The application of local wisdom is indeed not easy because the people of Indonesia adopt so many external currently. However, the opportunity to promote local wisdom as a conflict resolution still exists. This is in accordance with the opinion of Moendardjito in Ayatrohaedi that the element of regional culture has potential as local wisdom because of its ability to survive passing time. He exemplifies four characteristics of local wisdom for conflict resolution as follows.

1. Local wisdom is able to survive against external culture.

2. Local wisdom has the ability to accommodate outside cultural elements.

21 Herlina Astri, "Penyelesaian Konflik Sosial Melalui Penguatan Kearifan Lokal”, Aspirasi, Vol. 2, No. 2, Desember 2011, p. 15.

22 P.S. Atiyah, "Law \& Modern society", in Bagir Manan, Sistem Peradilan Berwibawa (Suatu Pencarian), $1^{\text {st }}$ edition, Yogyakarta: Penerbit UII Press, 2005, pp. 33-34.

23 Ibid., p. 34.

$24 \quad$ lbid., p. 35. 
3. Local wisdom has the ability to integrate external cultural elements into indigenous culture.

4. Local wisdom has the ability to control.

5. Local wisdom is able to give direction to cultural development.

South Sulawesi consists of four ethnic groups (Bugis, Makassar, Mandar, and Toraja) that has local wisdom as guidance, namely Siri'na pacce. Siri'na pacce has four elements $^{25}$, namely self-actualization, shame-and-guilt, loyalty, and honesty. Selfactualization is the desire of individuals to develop their own potential. Shame and guilt are a form of attitude that is felt by individuals when they cannot obey the rules in the community. Loyalty is the ability to carry out the mandate given. Honesty, that is, individuals behave according to their conscience. By absorbing each element of Siri'na pacce, individual works to develop potential, obey the rules in the community, be able to carry out the mandate, and do things consciously, and do not persecute.

The word Siri' in Makassarese means shame to do a disgraceful act. Even though the word may not understood only according to the literal meaning.

Some definitions of siri' are as follows. ${ }^{26}$

1. Matthes, as quoted by Koentjaraningrat, explains that the term siri' was translated as shame, or feeling effended, and so on.

2. According to Basjah, as quoted by Mattulada, there are three meanings of siri', namely shame, the driving force to destroy anyone who has offended someone's sense of honor, and a driving force to work or try as much as possible. ${ }^{27}$

3. Said says that siri' is a feeling of shame, which gives a moral obligation to kill those who violate adat, especially in matters of marital relations.

Based on the type siri' is divided into the following. ${ }^{28}$

1. Siri' Nipakasiri' deals with personal self-esteem, including family dignity. For instance, when someone is insulted or treated outside of humanitarian boundaries. Therefore, the victim (or the family) must uphold Siri' to restore dignity, honor, prestige. If they not do that, it is called mate siri', the death of honor and dignity. ${ }^{29}$ This type of Siri' is taboo and abstinence to be violated because the stakes are lives. An example in this case is to take away a girl. The family of the girl who is taken away must kill the perpetrator because she has embarrassed her family. In the belief of the Bugis-Makassarese people, the people who are killed for enforcing Siri' are martyrs, referred to as Mate Risantangi or Mate Rigollai. The death is like a death wrapped in coconut milk or sugar. In the Dutch Colonial era, Dutch Judges even could not understand why a Bugis-Makassarese can be so proud and admitted gently before the criminal court to conduct murder, even though the perpetrator knew that the criminal threat was very heavy compared with ordinary

25 Mughny Ilman Wali Rusdi, Susanti Prasetyaningrum, “Nilai Budaya Siri'na Pacce Dan Perilaku Korupsi: Pustaka Refleksi", Jurnal Indigenous, Vol. 13, No. 2, 2015, p. 70.

26 Koentjaraningrat, Manusia dan Kebudayaan di Indonesia, Jakarta: Djambatan, 2010, p. 22.

27 Mattulada, Latoa: Satu Lukisan Analitik Terhadap Antropologi Politik Orang Bugis, Ujung Pandang: Hasanuddin University Press, 1985, p. 62.

28 Rika Elvira, "Ingkar Janji Atas Kesepakatan Uang Belanja (Uang Panai') Dalam Perkawinan Suku Bugis Makassar", Skripsi, Fakultas Hukum Universitas Hasanuddin, Makassar, 2014, p. 30.

29 A.Moein MG, op.cit., p. 15. 
murder (unplanned murder as stipulated in Article 338 of the Criminal Code). Only native Bugis-Makassarese can understand the true meaning of Siri'. There is a saying reads "Sirikaji nanimmantang attalasa' ri linoa, punna tenamo siri'nu matemako kaniakkangngami angga'na olo-oloka", meaning "our Siri makes us still exist, embarrassment makes us not living like an animal, even more despicable than an animal. ${ }^{30}$ This kind of Siri is the driving force to eliminate (kill), alienate, expel, whoever offends them. So that if the event is met by law enforcers, it must pay attention to all aspects that are the background. The judge must pay attention to moral justice and social justice. It is in line with Article 5 of Law Number 48 of 2009 that "a judge must explore the living legal values in society", which includes moral justice and social justice. ${ }^{31}$

2. Siri' Mappakasiri'siri', Siri' Tappela' Siri' (Makassar) or Siri' Teddeng Siri' (Bugis) means that someone's shame is caused by something. For example, when a person has a debt and he has promised to pay it, he tries his best to keep his promise or pay his debt. When it reaches the predetermined time, if the debtor does not keep his promise, it means he has embarrassed himself. Bugis and Makassarese who still adhere to Siri' values do not need to be billed or charged. He pays it. The Siri' Mappakasiri'siri' makes the Bugis and Makasarese known for their high work ethic that lead to the success of Bugis and Makassar people overseas. By being motivated by the spirit of siri' Makassarese says, "Takunjunga bangun turu' naku gunciri' gulingku kualleangngangi tallanga na towaliya" (once the eyes open in the morning, aim the steering wheel, set the destination where the foot will move, determine to be better to sink rather than turn the bow to home before the ideals are reached). In addition, Siri' Mappakasiri'siri' can also prevent someone from doing things that are contrary to law, moral values, religion, customs and other actions that can harm humanity and dignity. Two of the Bugis philosophies in community life is "Mali' siparampe, malilu sipakainga" and "Pada idi' pada elo' sipatuo sipatokkong" or "Pada idi pada elo' sipatuo sipatottong". That is, when a relative is afflicted by a hardship or disaster, another family helps and if someone tends to fall into a pit of distress because of an error, the other family is obliged to warn and rectify it.

3. Siri' Masiri is a view of life that intends to maintain, to improve, or to achieve seriously by exerting all efforts for the sake of siri' itself. A piece of the Sinrili poem says, "Takunjunga' bangung turu' Nakugunciri' gulingku. Kuallengi Tallanga Natoalia", which means "I have laid my body down, I have set my steering wheel, I chose to sink rather than tide". The Bugis has expression "Narekko sompe'ko aja" muancaji ana'guru, ancaji Punggawako" (If you go wander, do not become a subordinate but strive to be a leader). ${ }^{32}$ The expression symbolizes how the BugisMakassarese people has a high determination and courage in life.

4. Siri' Mate Siri' is related to faith. In the view of the Bugis-Makassarese, the person whose mate siri' is the one who has no shame (faith). The person is viewed like

30 Rika Elvirah, op.cit., pp. 30-31.

31 Ahmad Rifai, Penemuan Hukum Oleh Hakim Dalam Perspektif Hukum Progresif, Cirebon: Sinar Grafika, 2010, p. 127.

${ }^{32}$ A. Moein MG, op.cit., p. 15. 
living carcasses. In short, the person is despicable and disillusioned. This type of person will dare to do corruption, collusion, nepotism, faking decisions, stealing budget, and faking taxes.

5. Pacce (Makassar) or Pesse (Bugis) is a value system within the Bugis-Makassarese. It is motivated by Siri' (shame) values. For example, if a child is disobedient to the parents (shame the family) then the child who has made a shame (siri') is discarded and crossed out from the family list. However, if at any time, when the parents hear or see the child suffer and live in disarray, the child can be taken back.

6. Punna tena siri'nu pa'niaki paccenu means that even if you are angry because a child has embarrassed the family, it is even more miserable to see your child suffer. If you are not shy, raise compassion in your heart (Paccenu). The child is God's trust that should not be wasted.

7. Pacce' in its literal sense means "poignant". Culturally, it means compassion, humanity, a sense of belonging, concern for help, or universal humanism. Therefore, pacce' is a feeling (statement) of solidarity that rises from within the heart, which can stimulate an action. This is the moral statement of BugisMakassarese. Pacce' is from inner to outer, vice versa, siri' is from outer to inner. It is Siri' and Pacce' that directs the behavior of the community in everyday life, a "motor" that drives the manifestation of cultural patterns and social systems.

8. Pacce' is a conscience to express the attitude of social solidarity towards the enforcement of the siri' together. It encourages the act of helping, the existence of demands for defense, and all other similar facts in solidarity that gets its life from the concept of siri'. The concept of pacce' is manifested as a sense of solidarity to defend and to help others. It is expressed in the idiom "abbulo sibatang" or in the Bugis phrase "mali siparappe, rebba sipatokkong, malilu sipakainge". The abbulo sibatang spirit means high sense of solidarity to help each other, in facing every challenge and difficulty. The spirit of mutual respect, which in the Bugis phrase is called sipakatau, also accompanies the sense of solidarity. Sipakatau is a manifestation of Siri' and Pacce', which is an awareness of the quality of human being. Self-actualization is possible only because of other human beings.

Siri'na pacce is a culture that has been institutionalized and trusted by the Makassarese. The Makassarese who inhabit South Sulawesi are indigenous people who already have their own cultural institutions, long before the official birth of the kingdom of Gowa, which was a kingdom with considerable influence. To explore the history of siri'na pacce, we can see writings on philosophy or advices on the writing of lontarak. Daeng Pamatte made the letter Lontarak when Karaeng Tumapakrisik Kallonna instructed him based on the kingdom's need to be able to communicate in writing and that royal events could be recorded in writing.

Deepening the meaning of siri' with all the problems can be traced in Lontarak La Toa. This lontarak contains messages and advice, which is a collection of admonitions to be used as role models. The word La Toa itself actually means advice, which is also in line with the role of siri' in the lifestyle or customs of the Bugis-Makassarese. For example, it can be seen at several points in the Lontarak: Siri' as dignity or honor; 
Mapappakasiri' means tarnishing honor; Siri Ritaroang means upheld honor; Passampo Siri' means closing shame, Siri 'as a manifestation of assertiveness for an honor life.

Although the history of the Makassarese began to be recorded during the Karaeng Tumapakrisik Kallonna, the culture of siri' has been a tradition and philosophy of their lives since a long time ago. The views of the Makassarese about siri' can be seen from several terms related to siri'. Siri 'can also be interpreted as an attitude statement that is not greedy and a life principle of the Bugis-Makassarese. Expressions such as siri' na ranreng (siri' at stake for honor), palaloi siri'nu (uphold your siri'), tau de 'siri'na (people without shame have no self-respect) are the idioms of the Bugis-Makassarese philosophy.

Siri' which is a concept of awareness of the law and philosophy of the BugisMakassarese can be considered sacred in all aspects of life. It also applies to aspects of the observance of certain rules (law), with an understanding of the value of Siri'na Pacce that greatly affects the community in legal life. Therefore, if someone loses Siri', then he or she has no dignity as a human. There is even an opinion that they are Sirupai olo 'kolo' (like animals). A Bugis adage says, Siri'mi Narituo (shame makes us alive). For the Bugis-Makassarese, there is no purpose or reason for life that is higher than to guard Siri' and if they are offended or humiliated (Nipakasiri), they prefer to die with a fight to restore their Siri' rather than live without Siri'.

Indeed, siri'na pacce is a shame culture that forms a person's mood, especially in the event of violation of social norms and values. The mood that is formed due to the existence of siri'na pacce does not care about the soul and property of others, resulting in a sacrifice. A sacrifice will not bring up a guilt culture but it will be felt as pride because it involves self-esteem. If this is reflected in behavior, whatever profession a person has will be carried out as well as possible and will carry out obligations rather than demanding too many because siri'na pacce culture demands people to carry out their obligations for social responsibility. In addition, upholding self-esteem in work make individuals more active, trustworthy, and honest. It cannot be separated from the brotherhood of fellow Bugis-Makassarese with mutual respect (Sipakalakbirik). Therefore, Siri'na pacce gives a positive impact, as reflected in the Makassarese sayings, Paentengi Siri'nu Sa'ribattang Nanupakniak Paccenu (everyone has shame and a willingness to sacrifice in defending a truth). This requires a courage to take a position to remain be on the path of truth with honesty, smart in responding to every problem and situation, and still surrender to the God Almighty.

The intended value of Siri'na pacce is not like an understanding that is now experiencing simplification into an easily angry attitude because it feels its existence is disturbed and hurt. The concept is taken from the teachings of the ancestors of the people of South Sulawesi as courage combined with the breadth of knowledge and wisdom of attitudes and behavior.

From the results, it can be concluded that the siri'na pacce has reciprocal correlations with acts of persecution. This means that the greater the cultural value is adopted and applied in the daily lives of the Bugis-Makassarese, the smaller the potential for persecution actions that may be raised and vice versa. In addition, siri'na pacce is one of the factors that can foster great hope to continue to explore and to 
maintain the siri'na pacce value so that it can inspire the national legal system in the present and future as well as the values of local wisdom.

The expression of the attitude of the Bugis-Makassarese community is manifested through the words taro ada' taro gau (one word one deed). It is the determination or ideals and promises that must be fulfilled and proven in real action. This is also in line with the principles of abattireng ripolipukku (the origin of ancestors is always upheld, all of which I capture for the glory of my ancestors).

The siri'na pacce culture is something that is very much needed by this nation to become a great nation. The nation needs young figures who have established souls and characters because young people are the future leaders and owners of this nation. They must have a siri'na pacce so that this nation can become more sensitive to all kinds of problems. Value is something that is needed in every aspect of life and, in the legal context, this value is the reference of law enforcement. This value lives in a society and becomes a philosophy of life in a particular society. Siri'na pacce' in Bugis society is highly upheld as a philosophy in all aspects of life and this also applies in the aspect of community obedience to certain rules (law). This understanding of values (siri'na pacce') greatly influences society.

Siri 'which is a concept of awareness of law and philosophy of the BugisMakassarese is something that is considered sacred. Siri'na pacce (Makassar) or Siri'na Pesse' (Bugis) are two words that cannot be separated from the character of the BugisMakassarese in navigating life. The words are so sacred so that when someone loses siri' or de'ni gaga siri'na, the life has no dignity. Even the Bugis-Makassarese argues that they are sirupai or 'kolo'e (like animals). A Bugis adage says, Siri'mi Narituo (out of shame we live).

A leader with siri'na pacce culture can become a leader with courage and firmness but still wise. A leader who holds this principle can lead this nation towards a better direction because they have a sense of sensitivity to the environment. They are able to listen to the aspirations of the people they lead because it is in line with the concept of democracy.

The way to make this happen is by facilitating interested parties such as victims, perpetrators, families, or communities to conduct mediation based on siri'na pacce values. This mediation can be done outside the court or in court. This mediation is full of the values of sirina pacce local wisdom, which can be an alternative solution to settle a dispute.

This research expects the community can better interpret the meaning of a culture, especially siri'na pace. It will make people more useful especially in carrying out personal life and as members of society. Aside from being a guideline in everyday life, siri'na pacce's cultural values are also a tool to control attitudes and behavior of each individual and to form a more moral and ethical society. Thus, it is expected that the values of sirina pacce must be maintained and preserved and able to minimize the occurrence of community conflicts, including persecution. 


\section{H. Obstacles to the Implementation of Siri'na pacce}

In the process of applying the siri'na pacce culture, several factors may become obstacles $^{33}$ in determining the form of conflict resolution that is appropriate to the needs of the local community, such as

1. The dynamics of community-based local political battles by using symbols of certain ethnicities;

2. The occurrence of 'thuggery' as a tool to gain power;

3. The pattern of community settlement that is still fragmented based on interests and socio-economic status that can hinder the process of acculturation and assimilation of culture;

4. Limited means of transportation, communication, and information for the community that facilitate the occurrence of disinformation - provocation on certain issues that are considered sensitive and trigger horizontal conflicts;

5. The efforts to fulfill the basic needs of many people that are not optimal (poverty, low levels of education, and quality of public health);

6. The structure of policies that are still not in favor of the interests of the people;

7. Exploitative management of natural resources that does not provide space for many people;

8. Weak capacity of local politicians in managing conflicts; Unemployment and increasing poverty widen social inequality between groups or communities leading to the oppression on certain ethnicities that is also marginalized in social interaction; and

9. The lack of law enforcement to deal with conflict and the weak capacity of law enforcement officers in managing conflicts.

These obstacles should be overcome by the direct involvement of communities in planning, implementing, and evaluating social conflicts around them. It is especially related to the causes of conflict and the potential of social conflict. This is very necessary because the community is a source of information and an executor of local wisdom of the siri'na pacce. Putting the community as a driving force for the running of local wisdom in an area means placing the community to grow and to maintain trust, togetherness, leadership, social networks, and so on. ${ }^{34}$

\section{Conclusion}

The increasing cases of persecution have led to the building of negative stigma and public distrust of the state and the law enforcement process. Persecution as an act of crime is harmful, troubling, and oppressing others so that it is considered criminal offense. The siri'na pacce value can be implemented and developed as an alternative solution to persecution because it is in accordance with the concept of legal objectives that are still upheld as a philosophy in all aspects of life and obedience to society because it is more rooted and considered sacred. By re-instilling the culture, the act of persecution can be prevented. It is expected that this cultural value can be maintained

\footnotetext{
${ }^{33}$ Herlina Astri, op.cit., pp. 159-160.

${ }^{34}$ Herlina Astri, op.cit., p. 159.
} 
and become an alternative solution to the act of persecution, which is more effective and efficient because it is easily accepted by the community.

The application of customary law with an approach to the value of shame and empathy for individuals and communities that prioritizes a win-win solution is one of the options that is often preferred by the community. It is felt capable to meet the sense of justice compared to resolving problems through the court that are sometimes hindered. Moreover, the settlement of criminal cases by using a repressive approach as implemented in the Criminal Justice System has resulted in retributive justice, which is oriented towards retribution in the form of punishment and imprisonment, so that it is less productive for all parties, especially victims.

The sirina pacce value can be an alternative solution to avoid persecution not only to the South Sulawesi region itself but also as a reference to resolve persecution in other regions. It is based on values and culture that are equal. Therefore, interpreting and instilling siri'na pacce's values can will make people able to carry out personal life and as members of society.

Aside from being a guideline in daily life, siri'na pacce's cultural values are also a tool to control the attitudes and behavior of each individual and to form a more moral and ethical society. By re-instilling the value of shame may prevent someone of persecution. The customary rules can strengthen the motivation of social solidarity in upholding Siri' na pacce. It can be maintained and become an alternative solution to persecution since it is more effective and efficient. Therefore, it is expected that the values of siri'na pacce must be maintained and preserved.

\section{References}

\section{Books}

A. Moein MG, Sirik Na Pacce, Kualleangnga Tallanga Na Toalia, Yayasan Makassar Press, Ujung Pandang, 1994.

Abdul Jamil Wahab, Manajemen Konflik Keagamaan Analisisi Latar Belakang Konflik Keagamaan Aktual, Elex Media Komputindo Kompas-Gramedia, Jakarta, 2014.

Ahmad Rifai, Penemuan Hukum Oleh Hakim Dalam Perspektif Hukum Progresif, Sinar Grafika, Cirebon, 2010.

Bagir Manan, Sistem Peradilan Berwibawa (Suatu Pencarian), $1^{\text {st }}$ edition, Penerbit UII Press, Yogyakarta, 2005.

Esmi Warassih, Pranata Hukum (Sebuah Telaah Sosiologis), Badan Penerbit Universitas

Diponegoro, Semarang, 2011.

Nurdin Yatim, Sub Sistem Honorifik Bahasa Makassar Sebuah Analisis Sosiolinguistik, Direktorat Pembinaan Penelitian dan Pengabdian pada Masyarakat (Dirjen Dikti), Jakarta, 1983.

Mattulada, Latoa: Satu Lukisan Analitik Terhadap Antropologi Politik Orang Bugis, University Press, Ujung Pandang, 1985.

Onong Uchjana Effendy, Ilmu, Teori dan Filsafat Komunikasi, Citra Aditya Bakti, Bandung, 2003.

R. Sugandhi SH, KUHP dan Penjelasannya, Usaha Nasional, Surabaya, 1980. 
S.R. Sianturi, Tindak Pidana di KUHP berikut uraiannya, Alumni AHM-PTHM, Jakarta, 1983.

Satjipto Rahardjo, Mendudukan Undang-undang Dasar (Suatu Pembahasan dari Optik IImu Hukum), Badan Penerbit Universitas Diponegoro, Semarang, 2007.

Sudikno Mertokusumo, Teori Hukum, Cahaya Atma, Yogyakarta, 2012.

\section{Other Documents}

Agen Sindikat, "Kamus Hukum Terlengkap - 11.000 istilah bahasa Inggris \& Belanda", https://www.academia.edu/16083005/Kamus Hukum Terlengkap -

11.000 istilah bahasa Inggris and Belanda, accessed on July 2018.

Amzulian Rifai, "Kejahatan Persekusi atau Tindakan Intimidasi?", https://nasional.sindonews.com/read/1211732/18/kejahatan-persekusi-atautindakan-intimidasi-1496878262, accesed on July 2018.

Bagir Manan, "Mediasi Sebagai Alternatif Menyelesaikan Sengketa", Varia Peradilan, No. 248, July 2006.

Herlina Astri, "Penyelesaian Konflik Sosial Melalui Penguatan Kearifan Lokal", Aspirasi, Vol. 2, No. 2, Desember 2011.

Hijriani Hadz, "Budaya Indonesia Jaman Now", https://locita.co/esai/persekusi-budayaindonesia, accessed on July 2018.

IAIN Tulungagung, "Persekusi Menurut Hukum Pidana", http://repo.iaintulungagung.ac.id/8157/6/BAB\%20III.pdf, accessed on July 2018.

Kementerian Pendidikan dan Kebudayaan RI, "Kamus Besar Bahasa Indonesia", https://kbbi.kemdikbud.go.id/persekusi, accessed on July 2018.

Koentjaraningrat, Manusia dan Kebudayaan di Indonesia, Djambatan, Jakarta, 2010.

Martinus Sitompul, "Empat Jeratan Hukum untuk Pelaku Persekusi", https://kumparan.com/@kumparannews/polisi-ada-empat-jeratan-hukum-untukpelaku-persekusi, accessed on July 2018.

Mughny IIman Wali Rusdi, Susanti Prasetyaningrum, "Nilai Budaya Siri'na Pacce Dan Perilaku Korupsi: Pustaka Refleksi", Jurnal Indigenous, Vol. 13, No. 2, 2015.

Mustafa, "Persekusi dalam Perspektif Komunikasi", https://uinsuska.ac.id/2017/07/11/persekusi-dalam-perspektif-komunikasi/, accessed on July 2018.

Rika Elvira, "Ingkar Janji Atas Kesepakatan Uang Belanja (Uang Panai') Dalam Perkawinan Suku Bugis Makassar", Skripsi, Fakultas Hukum Universitas Hasanuddin, Makassar, 2014.

Yayasan Lembaga Bantuan Hukum, "Artikel Diskusi Persekusi", http://www.ylbhi.or.id/2017/07/artikel-diskusi-persekusi/, accessed on July 2018.

\section{Law Documents}

1945 Constitution of the Republic of Indonesia. Indonesian Criminal Code [Kitab Undang-Undang Hukum Pidana].

Law Number 26 of 2000 on Human Rights Courts [Undang-Undang Nomor 26 Tahun 2006 tentang Pengadilan Hak Asasi Manusia]. 
Law Number 19 of 2016 on the Amendments to the Law Number 11 of 2008 on Information and Technology. [Undang-Undang Nomor 19 Tahun 2016 tentang Perubahan atas Undang-Undang Nomor 11 Tahun 200 tentang Informasi dan Transaksi Elektronik].

Rome Statute of the International Criminal Court 1998. 